\title{
Transient Homologous $\mu$-Opioid Receptor Desensitization in Rat Locus Coeruleus Neurons
}

\author{
G. C. Harris and J. T. Williams \\ The Vollum Institute, Oregon Health Sciences University, Portland, Oregon 97201
}

\begin{abstract}
Opioid agonists hyperpolarize neurons of the locus coeruleus (LC) in the slice preparation. When opioids were applied at concentrations that caused a maximum hyperpolarization, the membrane potential hyperpolarized to a peak (about 30 $\mathrm{mV}$ ) in the first minute and then declined over a period of 5 min. In addition, following the washout, the amplitude of the hyperpolarization induced by a lower concentration of opioid was significantly reduced as compared to control. The original response to both the low and the high concentrations of opioid recovered after removal of opioids for about 20 min. The decline in response, termed "acute desensitization," was observed only with concentrations of opioids that caused a maximum hyperpolarization and was dependent on the concentration of opioid applied $\left(\mathrm{EC}_{50}\right.$ for $\left[\mathrm{Met}^{5}\right]$-enkephalin (ME), between 3 and $5 \mu \mathrm{M}$ ). The response to ME ( $300 \mathrm{nM}$ ) was reduced to $6 \%$ of control following washout of a 5-min application of $\mathrm{ME}(30 \mu \mathrm{M})$, whereas the response to noradrenaline ( $300 \mathrm{nM}$ ) was reduced to $75 \%$ of control. The acute desensitization therefore was selective for the opioid receptor with marginal cross-desensitization to the $\alpha_{2}$-adrenoceptor-mediated hyperpolarization. The desensitization still occurred following treatment with $\beta$-chlornaltrexamine ( $\beta$-CNA), to decrease receptor reserve, as well as in cells taken from animals treated chronically with morphine. The mechanism for the acute desensitization was investigated using agents thought to alter kinase activity. This acute desensitization may represent an initial stage in the development of tolerance produced by chronic administration of opioids.
\end{abstract}

The locus coeruleus (LC) is a brain region used extensively to study both acute and chronic effects of opioid administration (Korf et al., 1974; Pepper and Henderson, 1980; Williams and North, 1984; Christie et al., 1987; Duman et al., 1988; Valentino and Wehby, 1989; Rasmussen et al., 1990) and is comprised of a homogeneous population of noradrenergic neurons that possess primarily $\mu$-subtype opioid receptors. Acutely, opioids inhibit adenylate cyclase (Duman et al., 1988; Beitner et al., 1989) and increase a potassium conductance that suppresses the spontaneous activity of LC neurons (Pepper and Henderson, 1980; Williams et al., 1982, 1988). Both the inhibition of ad-

Received Oct. 25, 1990; revised Feb. 28, 1991; accepted Mar. 21, 1991.

We thank Drs. M. J. Christie, R. Lester, and S. M. Johnson for comments on the work and manuscript. This work was supported by NIH Grants DA04523, MH45003, DA00141, and DA05387.

Correspondence should be addressed to J. T. Williams, The Vollum Institute, Orcgon Health Sciences University, 3181 Southwest Sam Jackson Park Road, Portland, OR 97201.

Copyright (C) 1991 Society for Neuroscience $0270-6474 / 91 / 112574-08 \$ 03.00 / 0$ enylate cyclase and the potassium conductance increase are mediated by the activation of a pertussis toxin-sensitive G-protein (Aghajanian and Wang, 1986).

Many G-protein-linked receptors have been found to exhibit diminished responsiveness (desensitization or tolerance) in the continued presence of agonists (Law et al., 1982; Benovic et al., 1986; Lefkowitz et al., 1990; Simmons et al., 1990). In the case of opioid receptors, the decline in receptor sensitivity found after prolonged agonist exposure can be specific for a single receptor subtype (homologous) or can also affect the responses of different receptor types (heterologous; Johnson and Flemming, 1989). Chronic treatment of animals with morphine has been shown to result in a homologous loss of opioid receptor sensitivity that is associated with a decrease in functional opioid receptors (Christie et al., 1987). This tolerance can be sustained for at least several hours after withdrawal of morphine. In the present experiments, we describe a transient reduction in opioid receptor sensitivity that occurs after a brief exposure to a high concentration of an opioid agonist. Experiments were designed to examine the concentration dependence, time course, receptor selectivity, and possible second messengers involved in the acute desensitization of the $\mu$-opioid receptor.

\section{Materials and Methods}

Subjects. Male Wistar rats (150-300 gm) were used for all experiments and housed according to NIH guidelines.

Tissue preparation. The exact details of the methods for slice preparation and recording have been reported elsewhere (Williams et al., 1984). Briefly, rats were anesthetized with halothane and killed. Horizontal slices of brainstem ( $300-\mu \mathrm{m}$ thickness) containing the LC were submerged in a tissue bath $(0.5-\mathrm{ml} \mathrm{vol})$ and superfused with artificial cerebrospinal fluid (CSF; $1.5 \mathrm{ml} / \mathrm{min}$ ) at $35^{\circ} \mathrm{C}$.

Apparatus. Microelectrodes were filled with $2 \mathrm{M} \mathrm{KCl}$ and had resistances of 30-50 M . Measurements of current and voltage were made with an Axoclamp-2A amplifier and recorded directly onto a chart recorder. Drugs were applied by superfusion. In all experiments [Met ${ }^{5}$ enkephalin (ME) was used in combination with the enkephalinase inhibitors thiorphan $(2 \mu \mathrm{M})$ and bestatin $(20 \mu \mathrm{M})$. In experiments using noradrenaline (NA), the slice was pretreated with cocaine $(3 \mu \mathrm{M})$ to prevent the reuptake of NA and prazosin (100 nM) to block any $\alpha_{1}$ adrenoceptor-mediated responses.

Chronic morphine treatment. Chronic morphine treatment consisted of the subcutaneous implantation of five time-release pellets that contained $75 \mathrm{mg}$ morphine, one on the first day and two on days 3 and 5 . Experiments were done on days 7-9 of treatment. Animals were defined as tolerant if the response to normorphine $(30 \mu \mathrm{M})$ was less than $65 \%$ of the maximum response to an $\alpha_{2}$-adrenoceptor agonist, UK 14304 $(1 \mu \mathrm{M})$. The response to normorphine in nontreated controls was $96 \pm$ $5 \%$ of UK $14304(1 \mu \mathrm{M})$ response.

Data analysis. The data were converted to change scores and analyzed using a one-way analysis of variance (ANOVA). Change scores reflected the difference in amplitude between the hyperpolarization induced by ME ( $300 \mathrm{nM}, 2 \mathrm{~min})$ before and after $(3 \mathrm{~min})$ a desensitizing application of $\mathrm{ME}(30 \mu \mathrm{M}, 5 \mathrm{~min})$. Similar change scores were calculated in the 


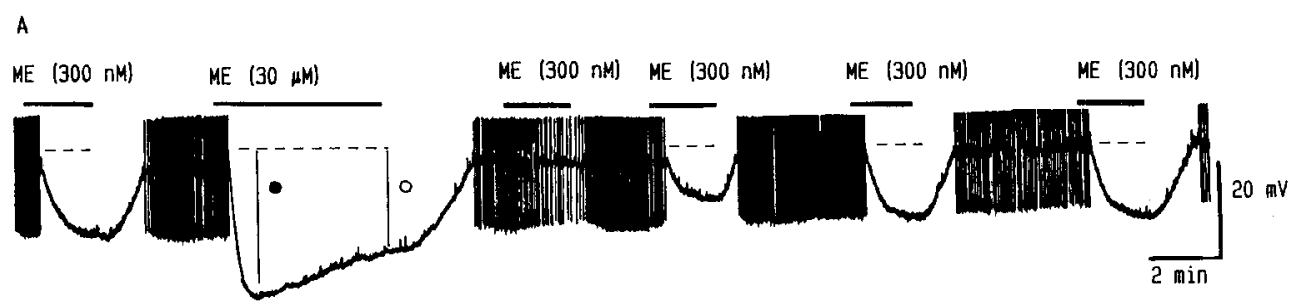

B

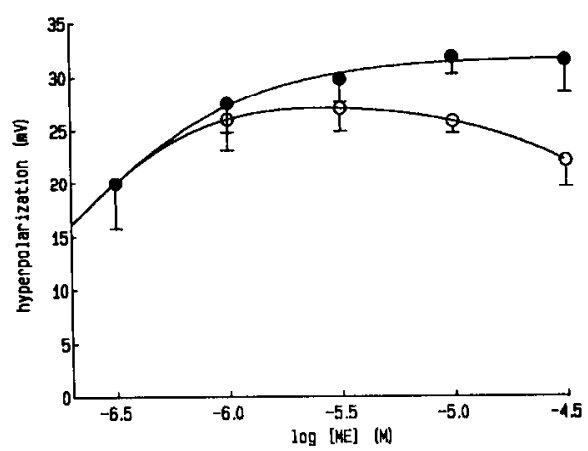

c

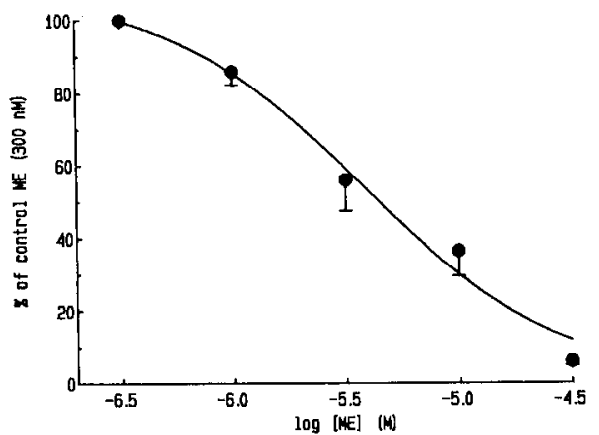

Figure 1. Desensitization of $\mu$-opioid receptors by ME. $A$, Recording of membrane potential from an $L C$ neuron. In this and other recordings of membrane potential, vertical deflections in the trace are spontaneous action potentials (the full amplitude is not shown). During the period indicated by the bar above the trace, the superfusion solution was changed to one that contained drug in the concentrations indicated. The first application of ME ( $300 \mathrm{nM}$ ) caused an inhibition of firing and a hyperpolarization of about $20 \mathrm{mV}$. ME (30 $\mu \mathrm{M})$ caused a hyperpolarization of about $30 \mathrm{mV}$ that declined during the 5-min application period. Immediately following the washout of $\mathrm{ME}(30 \mu \mathrm{M})$, the hyperpolarization induced by $\mathrm{ME}$ ( 300 nM) was reduced in amplitude, and with repeated applications, the full amplitude recovered. Broken line indicates the control membrane potential. $B$, The amplitude of the hyperpolarization at the peak (solid circles) and at the end of a 5-min application (open circles) is plotted as a function of $M E$ concentration. As the peak amplitude of the hyperpolarization increased to a maximum value, the response was not maintained. $C$, The response to $\mathrm{ME}(300 \mathrm{nM})$ is plotted as percentage of control immediately following a 5-min application of ME in the indicated concentrations. Error bars in $B$ and $C$ indicate the SEM. The amount of desensitization was increased as the concentration of ME was increased. The EC $\mathrm{E}_{50}$ was about $3 \mu \mathrm{M}$.

experiments with NA. Statistical comparisons between control and treatment groups were done in matched experiments, often on two slices from the same animal using the same stock solutions.

\section{Results}

\section{Acute desensitization}

Superfusion with ME (300 nM) caused an inhibition in the spontancous activity and a hyperpolarization of $-17 \pm 1.9 \mathrm{mV}(n$ $=9$ ). This hyperpolarization was sustained throughout the period of application (2-10 $\mathrm{min}$ ) and could be evoked repeatedly on the same neuron over a period of several hours (Williams and North, 1984). Higher concentrations of ME produced larger hyperpolarizations, but at these higher concentrations, the amplitude of the hyperpolarization declined during the application (Fig. $1 A$ ). The decline in the amplitude of the hyperpolarization was larger as the concentration of ME applied increased (Fig. $1 B)$. The peak hyperpolarization caused by ME (30 $\mu \mathrm{M})$ was $-32 \pm 3 \mathrm{mV}(n=8)$ and declined to $-22 \pm 3 \mathrm{mV}$ after $5 \mathrm{~min}$. When the response to $\mathrm{ME}(300 \mathrm{nM})$ was tested before and after a 5-min application of $\mathrm{ME}(30 \mu \mathbf{M})$, the amplitude of the hyperpolarization induced by the second test application was reduced $-1.2 \pm 0.3 \mathrm{mV}$, a mean change in amplitude of $16 \pm$ $1.0 \mathrm{mV}(n=9$; Fig. $1 A$, Table 1 ). Over a period of $20-25 \mathrm{~min}$, the amplitude of the hyperpolarization induced by ME ( $300 \mathrm{nM})$ returned to the original level. The decline of the hyperpolarization induced by high concentrations of $\mathrm{ME}$ and the following reduction in response to the lower concentration of $\mathrm{ME}$ suggest some form of desensitization. The ratio of response (after : before) of ME (300 $\mathrm{nM}$ ) decreased as the concentration of ME applied for a 5 -min test period was increased (Fig. 1C). Figure
$1 C$ indicates that the amount of desensitization was dependent on the concentration of agonist applied and that desensitization only occurred at concentrations above $1 \mu \mathrm{M}$, where the amplitude of the hyperpolarization had reached a maximum.

When high concentrations of other opioids ([D-Ala ${ }^{2}, N-\mathrm{Me}-$ $\mathrm{Phe}^{4}$,Gly ${ }^{5}$-ol]-enkephalin (DAMGO), 1 and $3 \mu \mathrm{M}$; normorphine, $30 \mu \mathrm{M})$ were superfused, the membrane potential hyperpolarized and the amplitude of the hyperpolarization declined during the continued application (Fig. 2, Table 2). The peak amplitude of the hyperpolarization induced by DAMGO was $-29 \pm 2.1 \mathrm{mV}$ at $1 \mu \mathrm{M}$ and $-35 \pm 1.5 \mathrm{mV}$ at $3 \mu \mathrm{M}$. After $5 \mathrm{~min}$, the hyperpolarization to DAMGO decreased to $-26 \pm 0.3$ (at $1 \mu \mathrm{M} ; n$ $=5$ ) and $-28 \pm 1.5 \mathrm{mV}$ (at $3 \mu \mathrm{M} ; n=6$; Table 2). Likewise, the normorphine induced hyperpolarization decline from a peak of $-31 \pm 1.2 \mathrm{mV}$ to $-27 \pm 0.4 \mathrm{mV}$ after $5 \mathrm{~min}(n=6)$. Because of the slow washout of these agonists, we were not able to test a low concentration of opioid after the desensitizing concentrations. The results indicate that, while all three of the opioid agonists tested cause a qualitatively similar type of desensitization, the amount of desensitization was greater for the full agonists ME and DAMGO as compared to the partial agonist normorphine.

ME also caused desensitization of the responses to other $\mu$-opioid agonists. The $\mu$-opioid-selective agonist DAMGO (100 $\mathrm{nM})$ caused a hyperpolarization of $-25 \pm 1 \mathrm{mV}(n=6)$ that persisted throughout the application (20-30 min). During perfusion with DAMGO, ME ( $30 \mu \mathrm{M}$, in the continued presence of DAMGO) caused a further hyperpolarization that faded during a 5-min application (Fig. 3). After the washout of ME, the DAM$\mathrm{GO}$-induced hyperpolarization was transiently reduced in am- 


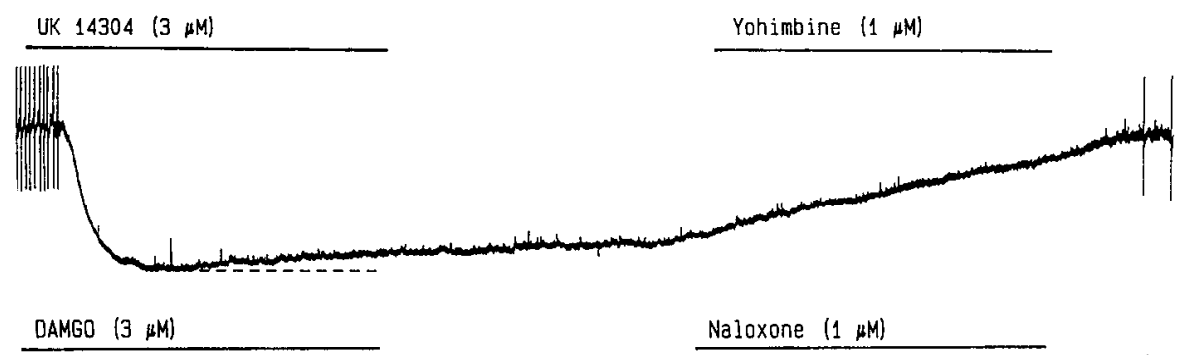

Figure 2. The decline in response during a 5-min application of UK 14304 $(3 \mu \mathrm{M})$, DAMGO $(3 \mu \mathrm{M})$, and normorphine $(30 \mu \mathrm{M})$. The broken line indicates the peak of the hyperpolarization induced by the agonists.

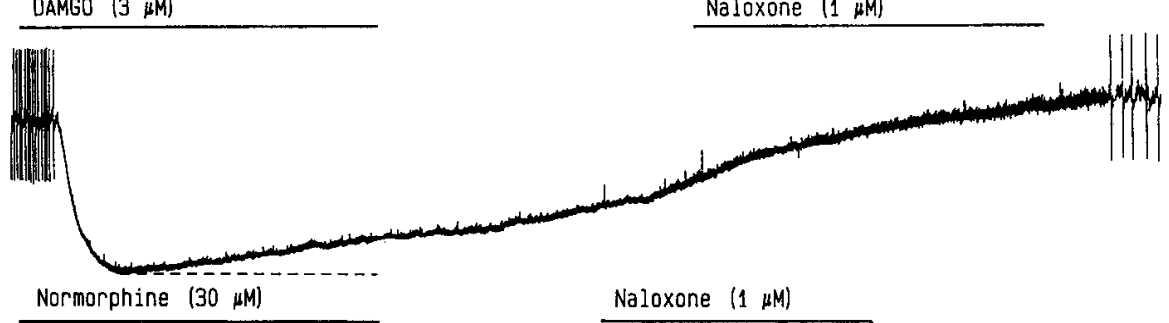

plitude to $-6 \pm 1 \mathrm{mV}(n=6)$. This transient decline peaked in 1-3 min and returned toward the initial value over a period of 15-25 min. Similarly, the hyperpolarization induced by morphine (100 nM; $-22 \pm 0.2 \mathrm{mV}$ ) was also reduced transiently to $-11 \pm 0.6 \mathrm{mV}(n=4)$ after superfusion with $\mathrm{ME}(30 \mu \mathrm{M})$. We interpreted the transient decline in hyperpolarization to DAM-
GO and morphine to result from receptor desensitization. These experiments also indicate that recovery from desensitization can occur even in the continued presence of a low agonist concentration.

Under voltage clamp ( $-60 \mathrm{mV})$, DAMGO (100 nM) caused an outward current $(230 \pm 20 \mathrm{pA})$ that declined transiently to

Table 1. Summary of results

\begin{tabular}{|c|c|c|c|c|c|}
\hline \multirow[b]{2}{*}{ Pretreatment } & \multicolumn{2}{|c|}{ Hyperpolarization (mV) } & \multicolumn{2}{|c|}{$\begin{array}{l}\text { Hyperpolarization }{ }^{a}(\mathrm{mV}) \\
3 \text { min after }\end{array}$} & \multirow[b]{2}{*}{$n$} \\
\hline & $\mathrm{ME}(300 \mathrm{nM})$ & $\mathrm{NA}(3 \mu \mathrm{M})$ & $\mathrm{ME}(30 \mu \mathrm{M})$ & $\mathrm{NA}(30 \mu \mathrm{M})$ & \\
\hline None & $-17 \pm 1.9$ & - & $-1 \pm 0.3$ & - & 9 \\
\hline None & $-17 \pm 1.4$ & - & - & $-16 \pm 1.0$ & 6 \\
\hline None & - & $-18 \pm 1.7$ & $-13 \pm 1.8$ & - & 5 \\
\hline None & - & $-17 \pm 1.2$ & - & $-11 \pm 1.6$ & 5 \\
\hline Staurosporin (3) & $-17 \pm 0.8$ & - & $-10 \pm 0.9^{* *}$ & - & 5 \\
\hline FSK (10) & $-25 \pm 3.5$ & - & $-12 \pm 3.7^{*}$ & - & 4 \\
\hline FSK (10) + IBMX (30) & $-24 \pm 2.3$ & - & $-11 \pm 3.4^{*}$ & - & 3 \\
\hline FSK (10) + IBMX (30) & & $-16 \pm 1.1$ & & $-11 \pm 2.0$ & 3 \\
\hline FSK (50) + IBMX (100) & $-22 \pm 4.0$ & - & $-10 \pm 2.8^{*}$ & - & 3 \\
\hline FSK $(100)+$ IBMX (100) & $-19 \pm 1.3$ & - & $-9 \pm 1.2^{*}$ & - & 3 \\
\hline 1,9-Dideoxy-FSK (100) & $-19 \pm 1.8$ & - & $-3 \pm 1.2$ & - & 3 \\
\hline 8-Bromo-cAMP (1 mM) & $-18 \pm 6.0$ & - & $-2 \pm 1.3$ & - & 3 \\
\hline Dibutryl cAMP (2 mм) & $-18+3.0$ & - & $-4 \pm 1.4$ & - & 3 \\
\hline None & $-21 \pm 1.2$ & - & $-2 \pm 0.5$ & - & 4 \\
\hline Chronic morphine & $-21 \pm 1.6$ & - & $-10 \pm 1.1^{*}$ & - & 7 \\
\hline Chronic morphine & - & $-16 \pm 0.9$ & - & $-11 \pm 1.5$ & 4 \\
\hline None & $-20 \pm 1.9$ & - & $-3 \pm 0.8$ & - & 6 \\
\hline $\mathrm{ME}(30 \mu \mathrm{M}, 5 \mathrm{~min})$ & $-17 \pm 1.3$ & - & $-7 \pm 1.1^{*}$ & - & 5 \\
\hline
\end{tabular}

Numbers in parentheses indicate concentration (in $\mu \mathrm{M}$ except where noted). FSK, forskolin. Values for the hyperpolarization are mean \pm SEM.

a Amplitude of hyperpolarization caused by the low concentration of ME (300 nM) or NA ( $3 \mu \mathrm{M}$ ) 3 min following washout of the high concentration of agonist indicated.

* Significantly different from control, $p<0.05$.

** Significantly different from control, $p<0.001$. 


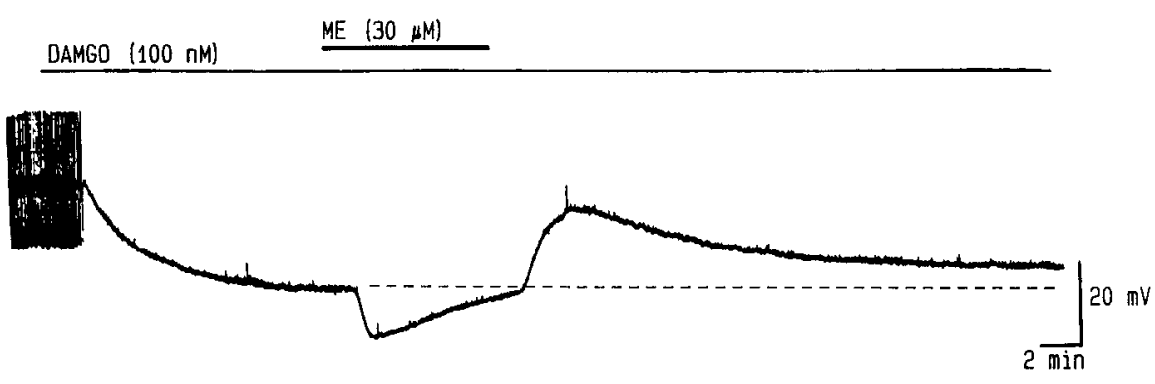

Figure 3. Desensitization and recovery from desensitization observed in the continued presence of a low concentration of agonist. Superfusion with DAMGO (100 nM) caused a 20-mV hyperpolarization of the membrane. When ME $(30 \mu \mathrm{M})$ was added to the DAMGO solution, there was a further hyperpolarization that declined over time. When the ME was washed out, there was a 15 $\mathrm{mV}$ decline in the hyperpolarization induced by DAMGO that recovered over a period of $15 \mathrm{~min}$. The broken line indicates the membrane potential reached at steady state during DAMGO.

$95 \pm 15 \mathrm{pA}(n=3)$ following the washout of a high concentration of $\mathrm{ME}(30 \mu \mathrm{M})$. The decline in the DAMGO current returned to control within $25 \mathrm{~min}(n=3)$. Thus, the decline in response to DAMGO was not dependent on the hyperpolarization of the membrane. In addition, current/voltage plots constructed at the peak of the response to a high concentration and following the decline in response (after $5 \mathrm{~min}$ ) indicated that the reversal potential of the opioid current did not change (Fig. 4). The $I / V$ curve obtained at the end of the 5-min application of ME (30 $\mu \mathrm{M}$ ) was subtracted from that taken at the peak of the response to construct an $I / V$ relationship of the desensitizing component. The reversal potential of the desensitizing component was -108 $\pm 2 \mathrm{mV}(n=9)$ in $2.5 \mathrm{~mm}$ potassium and was $-91 \pm 1 \mathrm{mV}$ $(n=3)$ in $6.5 \mathrm{~mm}$ potassium. These data indicate that during desensitization there was only a decrease in the maximum potassium conductance and not the appearance of another current.

\section{Receptor specificity}

Because $\alpha_{2}$-adrenoceptor agonists increase the same potassium conductance as opioid agonists (Andrade and Aghajanian, 1985; North and Williams, 1985), distinctions can be made between changes that occur at the level of $\mu$-opioid or $\alpha_{2}$-adrenoceptors from changes that occur along common signal transduction pathways. To test whether the desensitization was homologous for the $\mu$-opioid receptor, the hyperpolarization induced by $\alpha_{2}$ adrenoceptor activation was tested before and after desensitizing the cell to opioids. NA $(3 \mu \mathrm{M})$ caused a hyperpolarization of $-18 \pm 1.7 \mathrm{mV}(n=5)$ that was near the half-maximal hyperpolarization caused by $\alpha_{2}$-adrenoceptor activation. The hyperpolarization induced by NA $(3 \mu \mathrm{M})$ was reduced to $-13 \pm 1.8$ $\mathrm{mV}(n=5)$ after a 5 -min application of ME $(30 \mu \mathrm{M}$; Fig. $5 A$, Table 1). This heterologous desensitization of the NA-induced hyperpolarization was significantly less than the homologous desensitization seen with $\mathrm{ME}(300 \mathrm{nM})$ under the same conditions $[F(1,12)=72.47 ; p<0.0001]$.

We also tested ME (300 nM) before and after a 5-min application of $30 \mu \mathrm{M}$ NA, a concentration that caused a maximum hyperpolarization. After NA $(30 \mu \mathrm{M})$ had washed out, the response to $\mathrm{ME}(300 \mathrm{nM})$ was $-16 \pm 1.0 \mathrm{mV}(n=6$; Fig. $5 B)$, a mean change of $3 \pm 0.7 \mathrm{mV}$ from the original level. The reduction in response to $\mathrm{ME}(300 \mathrm{nM}$ ) following NA was significantly smaller than that following $\mathrm{ME}[30 \mu \mathrm{M} ; F(1,13)=85.32$; $p<0.0001]$. The initial response to $\mathrm{ME}(300 \mathrm{nM})$ recovered in $10 \mathrm{~min}$. These results indicate that there was some degree of heterologous desensitization between $\mu$-opioid and $\alpha_{2}$-adrenoceptors, but the striking desensitization to opioids was primarily homologous.

We also tested the ability of the $\alpha_{2}$-adrenoceptor agonists to cause desensitization in two ways. First, the amplitude of the hyperpolarization was examined during the application of a high concentration of agonist. The imadazoline agonist UK 14304 was used because it is a full agonist and not a substrate for uptake. UK 14304 caused a hyperpolarization of $-32 \pm 1.0$ $\mathrm{mV}$ at $1 \mu \mathrm{M}$ and $-32 \pm 1.6 \mathrm{mV}$ at $3 \mu \mathrm{M}$. These responses declined to $-31 \pm 0.6 \mathrm{mV}$ and $-29 \pm 1.3 \mathrm{mV}$, respectively, after $5 \mathrm{~min}$ (Fig. 2, Table 2). The decline in the hyperpolarization during a 5-min application of UK 14304 was smaller than that induced by the three opioids tested. Second, N $\Lambda(3 \mu \mathrm{M})$ was tested before and after application of a high concentration of NA $(30 \mu \mathrm{M})$. The second response to NA $(3 \mu \mathrm{M})$ was $-11 \pm 1.6$ $\mathrm{mV}$, a mean change of $6 \pm 0.5 \mathrm{mV}$ from the original response ( $n=5$; Fig. $5 C$, Table 1 ). This reduction was not significantly different from that seen when the high concentration of ME (30 $\mu \mathrm{M})$ was used. These results suggest that the desensitization to $\alpha_{2}$-adrenoceptor agonists was primarily heterologous. The concentration of NA used as the test dose $(3 \mu \mathrm{M})$ was chosen because it caused a hyperpolarization of the same amplitude as ME (300 $\mathrm{nM}$; Table 2). The desensitizing concentration of NA $(30 \mu \mathrm{M})$ was chosen because it was above that needed to produce the maximum hyperpolarization.

\section{Dependence on receptor number}

When the number of opioid receptors was decreased by pretreatment of the slice with the irreversible opioid receptor antagonist $\beta$-chlornaltrexamine $(\beta$-CNA; $20 \mathrm{~min}$ in $100 \mathrm{nM}$, wash for $60 \mathrm{~min})$, the hyperpolarization induced by $\mathrm{ME}(30-100 \mu \mathrm{M})$ was reduced to $35 \%$ of the control (compared to the hyperpolarization induced by UK 14304, $1 \mu \mathrm{M}$ ). The hyperpolarization induced by ME (30-100 $\mu \mathrm{M})$ declined during a 5-min application, and the subsequent application was $3 \pm 1.0 \mathrm{mV}$ smaller

Table 2. Desensitization of various $\mu$-opioid and $\alpha_{2}$-adrenergic agonists during a 5-min application

\begin{tabular}{|c|c|c|c|c|}
\hline Drug & Concentration $(\mu \mathrm{M})$ & $\begin{array}{l}\text { Hyperpolariza- } \\
\text { tion at peak }(\mathrm{mV})\end{array}$ & $\begin{array}{l}\text { Decline in } \\
\text { hyper- } \\
\text { polarization } \\
\text { after } \\
5 \text { min }(\mathrm{mV})\end{array}$ & $n$ \\
\hline UK 14304 & $\begin{array}{l}1 \\
3\end{array}$ & $\begin{array}{l}-32 \pm 1.0 \\
-32 \pm 1.6\end{array}$ & $\begin{array}{l}0.8 \pm 0.4 \\
2.7 \pm 0.3\end{array}$ & $\begin{array}{l}5 \\
6\end{array}$ \\
\hline DAMGO & $\begin{array}{l}1 \\
3\end{array}$ & $\begin{array}{l}-29 \pm 2.1 \\
-35 \pm 1.5\end{array}$ & $\begin{array}{l}3.0 \pm 0.0 \\
7.0 \pm 0.3\end{array}$ & $\begin{array}{l}5 \\
6\end{array}$ \\
\hline Normorphine & 30 & $-31 \pm 1.2$ & $4.2 \pm 0.4$ & 6 \\
\hline $\mathrm{ME}$ & 30 & $-32 \pm 3.0$ & $10.0 \pm 0.5$ & 8 \\
\hline
\end{tabular}

Values for hyperpolarization are the mean \pm SEM. 
Figure 4. Current/voltage plots for a cell under control conditions $(A)$, during the peak of the hyperpolarization by DAMGO $(3 \mu \mathrm{M} ; B)$, and after $5 \mathrm{~min}$ DAMGO $(3 \mu \mathrm{M} ; C)$. Left, extracellular potassium was $2.5 \mathrm{~mm}$ (normal solution). Right, the extracellular potassium was increased to $6.5 \mathrm{~mm}$ to show that the reversal potential of the DAMGO current and the desensitized current shifted to less negative potential.

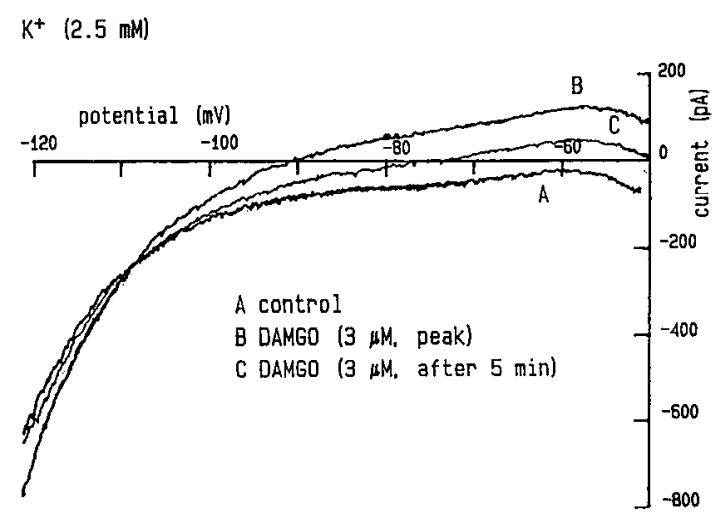

$K^{+}(6.5 \mathrm{mM})$

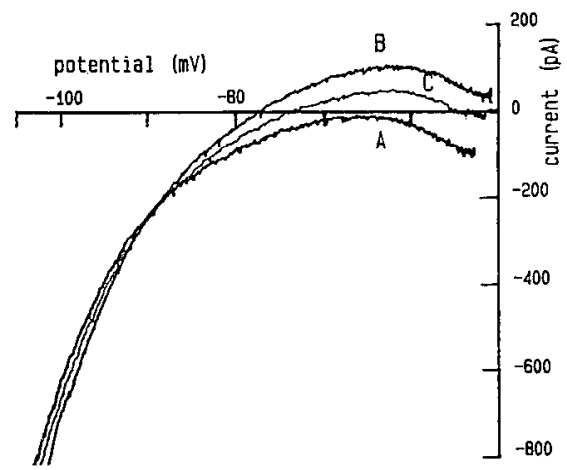

than beforc (Fig. $6 ; n=3$ ). The amplitude of the hypcrpolarization recovered to control levels within $17 \mathrm{~min}$ after washout $(n=3)$. This finding suggests that the desensitization process occurs at the level of single receptors and does not depend on the number of functional receptors or on the presence of a full response.

\section{Chronic morphine treatment}

To ascertain if there were any link between the changes induced by chronic opioid treatment and the acute desensitization process, acute desensitization experiments were done in animals treated chronically with morphine. The amplitude of the acute desensitization was reduced and recovery from desensitization was more rapid in cells from animals that were morphine treated $[F(1,11)=5.16 ; p<0.05$; Table 1]. Chronic opioid treatment did not, however, cause a significant change in the heterologous desensitization seen with NA ( $n=4$; Table 1$)$.

In experiments where slices were treated twice with high concentrations of opioids, the desensitization induced by the second application of $\mathrm{ME}(30 \mu \mathrm{M})$ was reduced from a change of $15 \pm$ $1.0 \mathrm{mV}$ to a change of $9 \pm 1.2 \mathrm{mV}(n=5$; Table 1). Therefore, a single application of a high concentration of opioids administered in vitro to a slice from a drug-naïve animal resulted in a change in the subscquent descnsitization responsc. The decline in the desensitization induced by a second application of a high concentration of opioids was not different from the desensitization found in slices taken from chronically morphine-treated animals.

\section{Role of second messengers}

In order to investigate the mechanisms by which opioid receptors desensitize, we tested the effects of agents that alter kinase activity (Table 1). First, agents known to increase intracellular cAMP levels were tested, including (1) forskolin $(10 \mu \mathrm{M} ; n=4)$, (2) forskolin and 3-isobutyl-1-methylxanthine (IBMX; 10, 50, or $100 \mu \mathrm{M}$ forskolin +30 or $100 \mu \mathrm{M}$ IBMX), (3) 8-bromo-cAMP ( $1 \mathrm{mM} ; n=3$ ), and (4) dibutyryl-cAMP ( $\mathrm{mM} ; n=3$ ). The cAMP analogs and lower concentrations of forskolin (with or without IBMX) increased spontaneous synaptic activity and tended to increase the firing ratc. Higher concentrations of forskolin and IBMX $(100 \mu \mathrm{M})$, however, hyperpolarized most cells. The hyperpolarization induced by $\mathrm{ME}$ at both the high $(30 \mu \mathrm{M}$; $-33 \pm 2 \mathrm{mV}$ ) and low ( $300 \mathrm{nM} ;-24 \pm 2 \mathrm{mV}$ ) concentrations were not changed by forskolin $(10,50$, or $100 \mu \mathrm{M})$ and IBMX (30 or $100 \mu \mathrm{M}$ ). Forskolin alone and in combination with IBMX caused a small but significant decrease in the amount of desen-
Figure 5. Evidence for heterologous desensitization. There was little crossdesensitization between opioid and $\alpha_{2}-$ adrenergic agonists and only a small desensitization of $\alpha_{2}$-adrenergic rcceptors. Recordings are of membrane potential from three LC neurons. All experiments were carried out in cocaine (3 $\mu \mathrm{M})$ and prazosin (100 $\mathrm{nM})$. The failure of the firing rates to return to normal in some instances is due to the residual effects of cocaine. $A$, The hyperpolarization induced by NA after a 5-min application of ME $(30 \mu \mathrm{M})$ was about $90 \%$ the control. $B$, The hyperpolarization induced by $\mathrm{ME}$ ( $300 \mathrm{nM})$ was about $75 \%$ of that before superfusion with NA $(30 \mu \mathrm{M}) . C$, The amplitude of the NA $(3 \mu \mathrm{M})$-induced hyperpolarization after application of NA $(30 \mu \mathrm{M})$ was about $90 \%$ of the control.
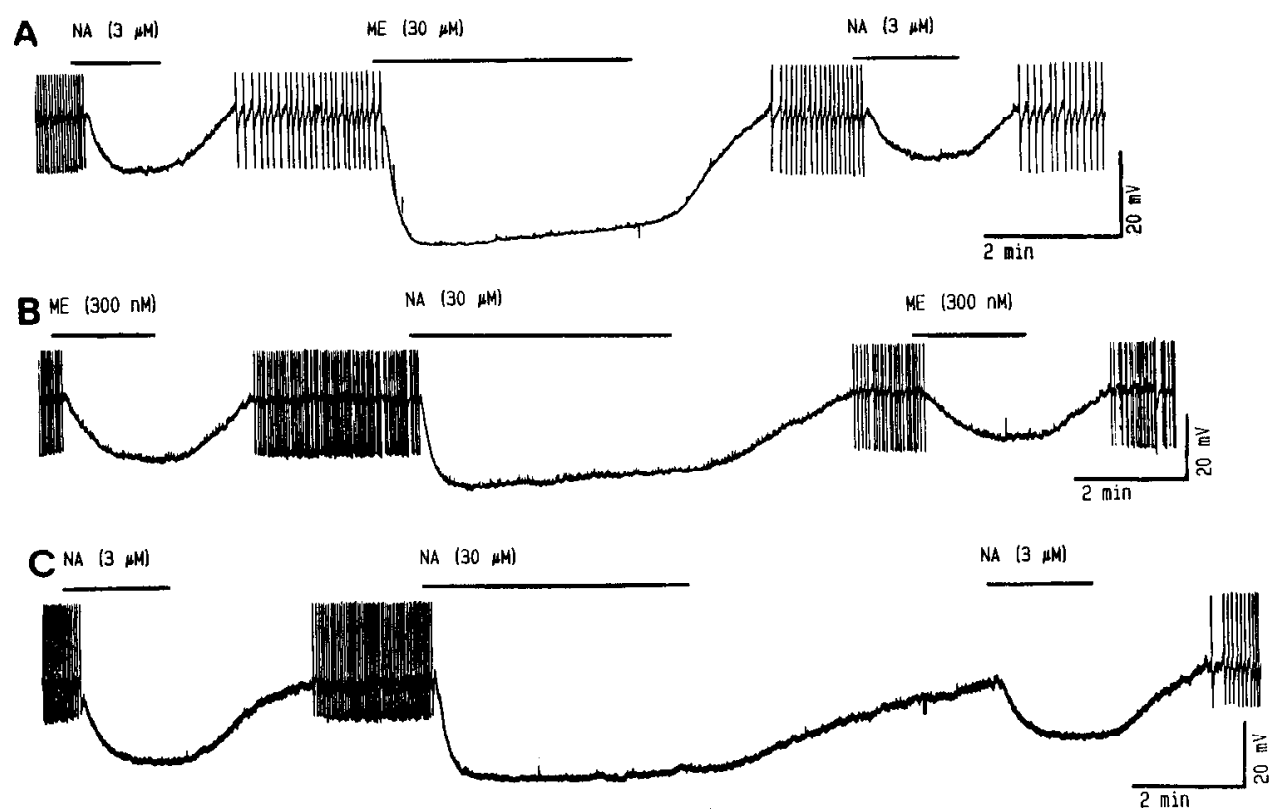


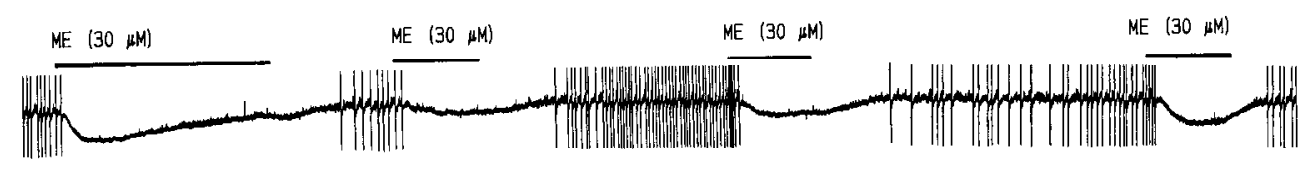

UK 14, $304 \quad(1 \mu \mathrm{M})$

Yohimbirte $(1-M)$

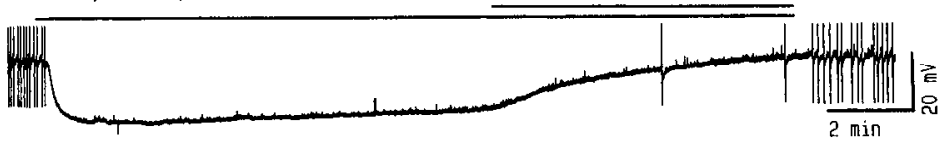

Figure 6. Desensitization to ME occurred after partial irreversible blockade of opioid receptors with $\beta$-CNA. Upper and lower traces are recordings from the same neuron in a slice that was treated with $\beta$-CNA. The hyperpolarization induced by $\mathrm{ME}(30 \mu \mathrm{M} ; u p$ per trace) was about $35 \%$ of that induced by UK 14304 ( $1 \mu \mathrm{M}$; lower trace), indicating that a substantial proportion of opioid receptors had been inactivated. The hyperpolarization induced by ME (30 $\mu \mathrm{M})$ declined during a 5-min application. Immediately following washout, the amplitude of the hyperpolarization was depressed and recovered after about $15 \mathrm{~min}$. sitization $[10 \mu \mathrm{M}$ forskolin, $F(1,6)=11.5 ; 10 \mu \mathrm{M}$ forskolin + $30 \mu \mathrm{M}$ IBMX, $F(1,5)=7.5 ; 50 \mu \mathrm{M}$ forskolin $+100 \mu \mathrm{M}$ IBMX, $F(1,5)=9.9 ; 100 \mu \mathrm{M}$ forskolin $+100 \mu \mathrm{M}$ IBMX, $F(1,5)=15.7$; Table 1). In contrast, neither of the cAMP analogs were able to change the amount of desensitization (Table 1). The inactive isomer of forskolin, 1,9-dideoxy-forskolin $(100 \mu \mathrm{M})$, did not alter the desensitization process, suggesting that this action of forskolin was somewhat specific. Finally, the heterologous desensitization to $\alpha_{2}$-adrenoceptor agonists was not affected by forskolin and IBMX (Table 1).

Second, a nonselective kinase inhibitor, staurosporin ( $3 \mu \mathrm{M}$; $n=5$ ), had no effect on the rate of spontaneous firing or the hyperpolarization induced by ME $(300 \mathrm{nM},-17 \pm 2 \mathrm{mV} ; 30$ $\left.\mu_{\mathrm{M}},-31 \pm 3 \mathrm{mV}\right)$. When applied for $20 \mathrm{~min}$, staurosporin reduced the amount and time course of desensitization seen to ME [Table $1 ; F(1,12)=41.25 ; p<0.001]$. Although the inhibition of desensitization by staurosporin was not complete and may not provide conclusive evidence for the involvement of protein kinase activation, it suggests that at least a part of the desensitization process may be mediated by increased kinase activity.

\section{Discussion}

The major finding of this study was that a brief exposure of LC cells to opioid agonists resulted in a concentration-dependent loss of opioid receptor sensitivity that was primarily homologous. This loss of receptor sensitivity recovered over a period of 20-25 min. The desensitization was dependent on neither the hyperpolarization of the membrane potential nor the absolute numbers of functional opioid receptors. Based on $I / V$ plots constructed at the peak of the response and after desensitization, it would seem that the apparent loss of receptor sensitivity was due primarily to a reduction of the receptor-mediated activation of the potassium conductance and not due to the appearance of a new current that counteracted this conductance. This is also suggested by the finding that the hyperpolarization induced by $\alpha_{2}$-adrenoceptor agonists, which activate a similar potassium conductance, was only marginally affected by desensitizing doses of opioids. In fact, high concentrations of full $\alpha_{2}$-adrenoceptor agonists seemed to cause little desensitization.

All three of the opioid agonists tested in this study were found to induce receptor desensitization as measured by the decline in response with continued application. Despite comparable hyperpolarizations, ME and DAMGO induced more desensi- tization than did normorphine. Previously it has been shown that normorphine is not a full agonist compared to ME and DAMGO in the LC (Christie et al., 1987), and this may account for its reduced ability to cause desensitization. In other studies, partial agonists such as morphine have been shown to be less potent in inducing both desensitization and downregulation of $\delta$-opioid receptors (Law et al., 1983). This observation suggests that the desensitization process of $\mu$-opioid receptors in the LC, like the desensitization of $\delta$-opioid receptors in NG 108 cells, is directly dependent on the ability of agonists to stimulate the receptor.

Opioid treatment for as little as $5 \mathrm{hr}$ has been shown to produce a loss of GTP regulation of opioid binding (Puttfarcken et al., 1988). This loss of GTP regulation of agonist binding is believed to be associated with the onset of receptor desensitization and the uncoupling of the receptor from the G-protein (Puttfarcken et al., 1988). Such a mechanism could account for the decline in receptor sensitivity found in this study and for the decline in functional opioid receptors found in the LC (Christie et al., 1987) and elsewhere (Porreca and Burks, 1983; Chavkin and Goldstein, 1984; Wimpey et al., 1989) following chronic morphine treatment.

The homologous desensitization of the opioid-induced hyperpolarization in LC neurons seen in this study was similar to the homologous desensitization reported for other G-proteinlinked receptors, such as $\beta$-adrenergic (Benovic et al., 1986; Sibley et al., 1987), muscarinic (Eva et al., 1990), and peptidergic (Law et al., 1983; Bosma and Hille, 1989; Simmons et al., 1990). In each case, high receptor occupancy was required for the desensitization that was specific for the receptor involved. The change in receptor sensitivity found in this study could result from a covalent modification of the receptor, such as phosphorylation, that allows the receptor to uncouple from the G-protein or to be sequestered into the cell. Such a mechanism has been found to occur in the case of the $\beta$-adrenergic receptor system, and several different protein kinases have been found to account for the combination of heterologous and homologous desensitization (Cheung et al., 1990; Eva et al., 1990; Lefkowitz ct al., 1990; Lohse ct al., 1990). Dircet cvidence for the phosphorylation-induced desensitization of the opioid receptor has not yet been obtained. The failure of the kinase inhibitor staurosporin to inhibit completely the desensitization process in the present experiment might suggest that there may be more than a single mechanism that mediates $\mu$-opioid receptor desensitization. 
It has been shown that the cAMP system changes in response to chronic exposure to opioids and may contribute to the adaptations of LC neurons to opioids (Andrade and Aghajanian, 1985; Aghajanian and Wang, 1987; Duman et al., 1988; Hayward et al., 1990). The present experiments indicate that, while the acute response to opioids was not altered by forskolin (and IBMX), the amount of desensitization was significantly decreased, though not completely blocked. The decrease in the desensitization did not increase with increasing concentrations of forskolin, suggesting that there was a limit to the ability of forskolin to alter the desensitization process. The inactive analog of forskolin did not alter the desensitization, further suggesting that the effects of forskolin were specific. Although the results with forskolin suggest the involvement of a cAMP-dependent mechanism, neither of the cAMP analogs tested in this study was effective in altering the desensitization process. One could postulate that the cAMP analogs did not reach sufficiently high intracellular concentrations or were less effective in activating cAMP-dependent mechanisms than was forskolin, or that forskolin had effects other than elevating intracellular cAMP.

Acute desensitization of the opioid receptor was also found to occur in chronically morphine-treated rats in the present study. The absolute amount of desensitization was less than that seen in controls, but was very similar to that seen in cells that received multiple exposures of desensitizing concentrations of opioids. This suggests that LC cells in animals treated chronically with morphine have "experienced" a high enough concentration of agonist to respond in the same way as cells that have been treated by superfusion with known supermaximal concentration of agonists. In addition, the responses of cells taken from the chronically morphine-treated rats were also quite similar to the responses seen in cells pretreated with forskolin and IBMX. The increases in adenylate cyclase activity found in the LC of chronically morphine treated rats may explain these similarities (Duman et al., 1988).

In the present study, recovery from desensitization occurred even in the presence of low agonist concentration, indicating that recovery could be initiated even while a proportion of receptors were occupied. This situation may actually arise in cases of opioid abuse where a higher concentration of opioid is administered in the continued presence of residual opioids. Plasma and presumably brain concentrations of morphine seen in vivo reach levels similar to that used in this study to produce desensitization (3-30 $\mu \mathrm{M}$ ) following intravenous administration (Sydney and Elliott, 1971; Garriott and Sturner, 1973). While the role of opioid receptor desensitization is unknown, it is clear that it does represent an initial adaptive change in response to occupation of the opioid receptor. As such, it may play some role in the initiation of the cascade of events requiring hours or days that eventually leads to opioid tolerance.

\section{References}

Aghajanian GK, Wang Y-Y (1986) Pertussis toxin blocks the outward currents evoked by opiate and $\alpha_{2}$-agonists in locus coeruleus neurons. Brain Res 371:390-394.

Aghajanian GK, Wang Y-Y (1987) Common $\alpha_{2}$ - and opiate effector mechanisms in the locus coeruleus: intracellular studies in brain slices. Neuropharmacology 26:793-799.

Andrade K, Aghajanian GK (1985) Opiate- and $\alpha_{2}$-adrenoceptor-induced hyperpolarization of locus ceruleus neurons in brain slices: reversal by cyclic adenosine $3^{\prime}: 5^{\prime}$-monophosphate analogues. J Neurosci 5:2359-2364.

Beitner DB, Duman RS, Nestler EJ (1989) A novel action of morphine in the rat locus coeruleus: persistent decrease in adenylate cyclase. Mol Pharmacol 35:559-564.

Benovic JL, Strasser RH, Daniel K, Lefkowitz RJ (1986) Beta-adrenergic receptor kinase: identification of a novel protein kinase that phosphorylates the agonist-occupied form of the receptor. Proc Natl Acad Sci USA 83:2797-2801.

Bosma MA, Hille B (1989) Protein kinase C is not necessary for peptide-induced suppression of $M$ current or for desensitization of the peptide receptors. Proc Natl Acad Sci USA 86:2943-2947.

Chavkin C, Goldstein A (1984) Opioid receptor reserve in normal and morphine-tolerant guinea pig ileum myenteric plexus. Proc Natl Acad Sci USA 81:7253-7257.

Cheung AH, Dixon RAF, Hill WS, Sigal IS, Stader CD (1990) Separation of the structural requirements for agonist-promoted activation and sequestration of the $\beta$-adrenergic receptor. Mol Pharmacol 37:775-779.

Christie MJ, Williams JT, North RA (1987) Cellular mechanisms of opioid tolerance: studies in single brain neurons. Mol Pharmacol 32: 633-638.

Duman RS, Tallman JF, Nestler EJ (1988) Acute and chronic opiateregulation of adenylate cyclase in brain: specific effects in locus coeruleus. J Pharmacol Exp Ther 246:1033-1039.

Eva C, Gamalero SR, Genazzani E, Costa E (1990) Molecular mechanisms of homologous desensitization and internalization of muscarinic receptors in primary cultures of neonatal corticostriatal neurons. J Pharmacol Exp Ther 253:257-265.

Garriott JC, Sturner WQ (1973) Morphine concentrations and survival periods in acute heroin fatalities. N Engl J Med 289:1276-1278.

Hayward MD, Duman RS, Nestler EJ (1990) Induction of the $c$-fos proto-oncogene during opiate withdrawal in the locus coeruleus and other regions of rat brain. Brain Res 525:256-266.

Johnson SM, Flemming WW (1989) Mechanisms of cellular adaptive sensitivity changes: applications to opioid tolerance and dependence. Pharmacol Rev 41:435-488.

Korf J, Bunney BS, Aghajanian GK (1974) Noradrenergic neurons: morphine inhibition of spontaneous activity. Eur J Pharmacol 25: $165-169$.

Law PY, Hom DS, Loh HH (1982) Loss of opiate receptor activity in neuroblastoma $X$ glioma NG108-15 hybrid cells after chronic opiate treatment. Mol Pharmacol 22:1-4.

Law PY, Hom DS, Loh HH (1983) Opiate receptor down-regulation and desensitization in neuroblastoma X glioma NG108-15 hybrid cells are two separate cellular adaptation processes. Mol Pharmacol 24:413-424.

Lefkowitz RL, Hausdorff WP, Caron MG (1990) Role of phosphorylation in desensitization of the $\beta$-adrenoceptor. Trends Pharmacol Sci 11:190-194.

Lohse MJ, Benovic JL, Codina J, Caron MG, Lefkowitz RJ (1990) $\beta$-Arrestin: a protein that regulates $\beta$-adrenergic receptor function. Science 248:1547-1550.

North RA, Williams JT (1985) On the potassium conductance increased by opioids in rat locus coeruleus neurons. J Physiol (Lond) 364:265-280.

Pepper CM, Henderson G (1980) Opiates and opioid peptides hyperpolarize locus coeruleus neurons in vitro. Science 209:394-395.

Porreca F, Burks TF (1983) Affinity of normorphine for its pharmacologic receptor in the naive and morphine-tolerant guinea-pig ileum myenteric plexus. J Pharmacol Exp Ther 225:688-693.

Puttfarcken PS, Werling LL, Cox BM (1988) Effects of chronic morphine exposure on opioid inhibition of adenylate cyclase in $7351 \mathrm{c}$ cell membranes: a useful model for the study of tolerance at $\mu$ opioid receptors. Mol Pharmacol 33:520-527.

Rasmussen K, Beitner-Johnson DB, Krystal JH, Aghajanian GK, Nestler EJ (1990) Opiate withdrawal and the rat locus coeruleus: behavioral, electrophysiological, and biochemical correlates. J Neurosci 10:2308-2317.

Sibley DR, Benovic JL, Caron MG, Lefkowitz RJ (1987) Regulation of transmembrane signaling by receptor phosphorylation. Cell 48 : 913-922.

Simmons MA, Becker JB, Mather RJ (1990) Desensitization of the inhibition of the M-current in sympathetic neurons: effects of ATP analogs, polyanions, and multiple agonist applications. Neuron 4: $557-562$

Sydney S, Elliott S (1971) Disposition of morphine in man. Science 174:421-422. 
Valentino RJ, Wehby RG (1989) Locus ceruleus discharge characteristics of morphine-dependent rats: effects of naltrexone. Brain Res 488:126-134.

Williams JT, North RA (1984) Opiate-receptor interactions on single locus coeruleus neurons. Mol Pharmacol 26:489-497.

Williams JT, Egan TM, North RA (1982) Enkephalin opens potassium channels on mammalian central neurons. Nature 299:74-77.

Williams JT, North RA, Shefner SA, Nishi S, Egan TM (1984) Membrane properties of rat locus coeruleus neurons. Neuroscience 13:137156.
Williams JT, North RA, Tokimasa T (1988) Inward rectification of resting and opioid-activated potassium currents in rat locus coeruleus neurons. J Neurosci 8:4299-4306.

Wimpey TL, Opheim KE, Chavkin C (1989) Effects of chronic morphine administration on the mu and delta opioid responses in the CA1 region of the rat hippocampus. J Pharmacol Exp Ther 251:405411. 